\title{
University Role in Liaising Partners for Society Development: A Case Study of a University Contribution to Society Development Through the Liaising Social Partners in Ghana
}

\author{
Paul Wabike (Corresponding author) \\ International Business School, Fontys University of Applied Sciences \\ P.O. Box 141, 5900 AC Venlo, The Netherlands \\ Tel: 31-640-299-9730Ｅ-mail: p.wabike@fontys.nl
}

Received: June 27, 2021 Accepted: August 9, $2021 \quad$ Published: August 17, 2021

doi:10.5296/jei.v7i2.18813 URL: https://doi.org/10.5296/jei.v7i2.18813

\begin{abstract}
Universities contribution to society development in Africa has been a subject of discussion since many countries attained independence in the 1960s. The university was seen as having a function of emancipating society from poverty and ignorance. The premise of this view was based on the university's role in creating the ruling elite and knowledge generation and dissemination, which could help societies deal with development challenges (Sawyerr, 2004). These challenges pertained to political stability, food security, diseases and infrastructure development. The recognition that universities contribute to society development is thus not new in Africa; however, little is understood of the mechanisms these universities employ to fulfil this role. Applying social capital concepts to a case study at the University of Cape Coast (UCC) in Ghana, this article asks the following question: how do universities contribute to society development by creating social capital? UCC engagement with the Yamoransa community is analysed using a University-Community Engagement (UCE) context. Results show that university-community engagement may hold the key to producing tangible results while meeting community development challenges by creating social capital. Social capital helps build community capabilities by allowing access to knowledge circles and resources for the actors in the network. However, structural contexts in which universities operate in Africa may influence university contribution to social capital creation and its perceived benefits to society.
\end{abstract}


Keywords: Social capital, University-Community Engagement (UCE), Society development, Networks

\section{Introduction}

The contribution of universities to the development of societies in Africa's Sub-Saharan region has been an area of political debate and academic tensions. The independence years of the 1960s and 1970s saw countries invest in universities, among other reasons, to train a capable elite class for ruling newly independent countries and territories (Sawyerr, 2004). Recently, there have been increased calls for the university in Africa to fulfil their third missions (Preece, 2017; Kruss, Visser, Aphane, \& Haupt, 2012; Cloete, Bailey, \& Pillay, 2011), with universities increasingly responding with attempts to address development challenges through various forms of community engagements (Preece, Ntseane, Modise, \& Osborne, 2012). The increased calls for university-community engagement in Africa are partly encouraged by achievements elsewhere, where universities and firms have partnered successfully in producing tangible products (Kruss et al., 2012; Cloete et al., 2011). Although there is evidence that the majority of the African universities engage communities in some form (Preece, 2017), Kruss (et al., 2012) suggest that this is often sporadic and mainly involves individual academic staff. With different engagement projects studied in Africa ( $c f$ Preece et al., 2012), there is still no clarity on how exactly does the university contribute to society development through working with communities around and beyond their geographical localities.

Human development is still lagging, with many countries, particularly sub-Saharan Africa, having almost half of their populations living under the poverty line (UNDP, 2019). The UNDP's Human Development Index (HDI) of 2019 shows that of the 40 lowest-ranked countries, $85 \%$ comes from Africa, and among the 68 countries listed as least developed, 45 are in Africa. Governments and other institutions implementing international development efforts such as the Millennium Development Goals (MDG 2000-2015) and the Sustainable Development Goals (SDG 2015-2030) in Africa may need to look into universities positions in accessing knowledge and resources for communities to develop.

This paper defines university-community engagement as a collaborative process between a university and a community that systematically or situationally enhances learning experiences to improve lives. However, universities have many other functions and operate in broader institutional and political-economic contexts that have a bearing in their capacities to realise this potential (Cloete et al., 2011). These contexts may enable or hinder the collaborative processes that contribute to society development. Social capital is used as a theoretical lens in understanding university contribution to society development. The case study is conducted in Ghana at the University of Cape Coast. The paper contributes to understanding how universities can play a role in society development by creating social capital.

\section{Social Capital}

The notion of social capital has been widely defined in the literature to include such terms as relations between actors, the structure of these relations, internal and external types of 
linkages among actors (bonding and bridging dimensions) (Grootaert \& Van Bastelaer, 2001). Also, a vertical hierarchical relation with people in institutions and organisations (the linking dimension) (Field, 2003). Social capital, according to Coleman (1988), is a structure of relations between actors. These relations form connections and networks among individuals and organisations (Putnam, 2000), including reciprocal trust, norms, values, and behaviours (Rudd, 2003; Misztal, 1996). In other words, social capital can be explained 'through changes in the relations among persons that facilitate actions' (Coleman 1988). Putnam (2000) defines social capital as the social organisation, such as trust, norms, and networks, that can improve the efficiency of society by facilitating coordinated actions. Also, the World Bank (2002) depicts social capital as the institutions, relationships, and norms that shape the quality and quantity of a society's social interactions and acts as the glue that holds social institutions together. In comparison, physical and human capitals are tangible, while social capital is less tangible and observable, exemplified in the relations among actors (Coleman 1994). In other words, social capital is a set of relationships among people - and those relationships are productive to the extent that they are based on a standard set of expectations, a shared set of values, and a sense of trust (Lockwood, 1996).

While Grootaert and Van Bastelaer (2001) recognise that other capitals (such as natural, physical and human) contribute to society development, they assert that these three types of capital determine only partially the process of economic growth because they overlook how the economic actors interact and organise themselves to generate growth and development. Though not unproblematic in definitions and applications, social capital can produce benefits that go beyond economic gains (Grootaert \& Van Bastelaer, 2001; Lin, 2001; Putnam, 2000). These benefits include social cohesion, increased social engagement (Moore, 2014; Putnam, 2000), education access and employability, and increased health, economic and social advancement (Woolcock \& Narayan, 2000). Putnam (2000) contends that social capital can resolve collective problems while increasing individual benefits by reciprocal cooperation, safeguarding observance in established norms and relieving the individual burden in carrying out their missions. Social capital can establish an environment in which people trust each other (Misztal, 1996; Coleman, 1994), which leads to repeated interactions and creates a cost-effective environment in both businesses and social transactions (Woolcock \& Narayan, 2000). These social interactions occur in formal and informal networks, and this process is concisely discussed here below.

\subsection{Social Capital and Networks}

According to Burt (2000), a network can be defined as a concrete (measurable) pattern of relationships among entities in a social space. Social capital is often depicted in two main concepts, connectivity embedded within networks. The connectivity is among and between individuals and organisations within particular networks. Lin (2001) points out that social capital's resources and how they are accessed are both embedded in social networks (or human relationships). Networks and how people connect within those networks are thus crucial mediums through which social capital notions such as civic behaviour, social norms, cooperation and social cohesion can be understood (Coleman, 1994; Rudd, 2003). 
Networks create social capital for individuals (Burt, 2000) and communities (Putnam, 2000). Individuals' associations can help them work for mutual benefits through their shared networks (Putnam, 2000). Through values attached to mutual benefits and shared networks, people can help each other and guard for their communities' collective actions. The degree to which community members are willing to work together and share knowledge and resources productively is manifest in how that community is cooperative and coordinated (Coleman, 1994).

Within human networks, SC is created through different activities including, but not limited to, partnerships (shared vision/ownership), collaboration (shared assets), and participation (shared conversational space). Social capital is created within formal and informal networks where people share ideas or practices to benefit those involved (Woolcock \& Narayan, 2000). It is acquired through the interaction of social actors-individuals in a network, networks with networks, and networks with organisations (Field, 2003; Putnam, 2000). These individuals or organisations are essential in defining actions and influencing (strategic) directions in which an individual or organisation goes (Lin, 2001).

According to Chatterton and Goddard (2003), social capital is the soft infrastructure linking individuals within networks in organisations and communities. Social organisation-relationships among and between individuals and social groups-forms the basis of the creation and use of social capital (Putnam, 2000; Coleman, 1994). Networks are closely linked to the creation of social capital. '... capital is represented by the size of the network and the volume of capital [...] possessed by those to whom a person is connected' and that this capital is collectively shared by members of a network that has '.. clear boundaries, obligations of exchange, and mutual recognition' (Lin, 2001).

The quality of the networks and the skills and competencies of those within networks consequently influence the quality of social capital output (Field, 2003). Putnam (2000) links declining social cohesion to increased crimes, poverty, and educational non-participation. Coleman (1988) argues that social capital is 'not a single entity, but a variety of different entities, having two characteristics in common: they all consist of some aspect of a social structure, and they facilitate certain actions of individuals who are within the structure' ( $p$. 302). Networks create capital through structures of relationships between and among individuals (Lin, 2001).

\subsection{Social Capital and the University}

It is in these structures that universities and communities can engage and share expertise for society development. Universities can contribute to society development by engaging in activities such as teaching and training and creating networks with different partners that enhance resources access and application (Brennan, King, \& Lebeau, 2004). By doing this, universities contribute to the transformation of society economically, politically and culturally. The Task Force on Higher Education and Society (TFHE, 2000) sees universities' contribution to this transformation as the (a) unlocking potential at all levels of society (offering advanced training to people regardless of their social backgrounds); (b) creating a pool of highly trained individuals; (c) addressing topics that encompass society as a whole 
and not of value to current students and employees only; and (d) providing inclusive discussion space for sharing ideas and values. According to Brennan et al. (2004), human capital lies in its formation, which sustains the state and civil institutions, encourages social structures, including mobility of different people, and enhances culture and cultural expressions. In creating a critical pool of highly trained individuals, universities produce a critical national resource that may help societies create innovative firms and networks of enterprises, microeconomic and regulatory frameworks, adequate communication infrastructures, and knowledge-producing organisations' (World Bank, 2002). As Figure 1 shows, the creation of capitals may lead to society development.

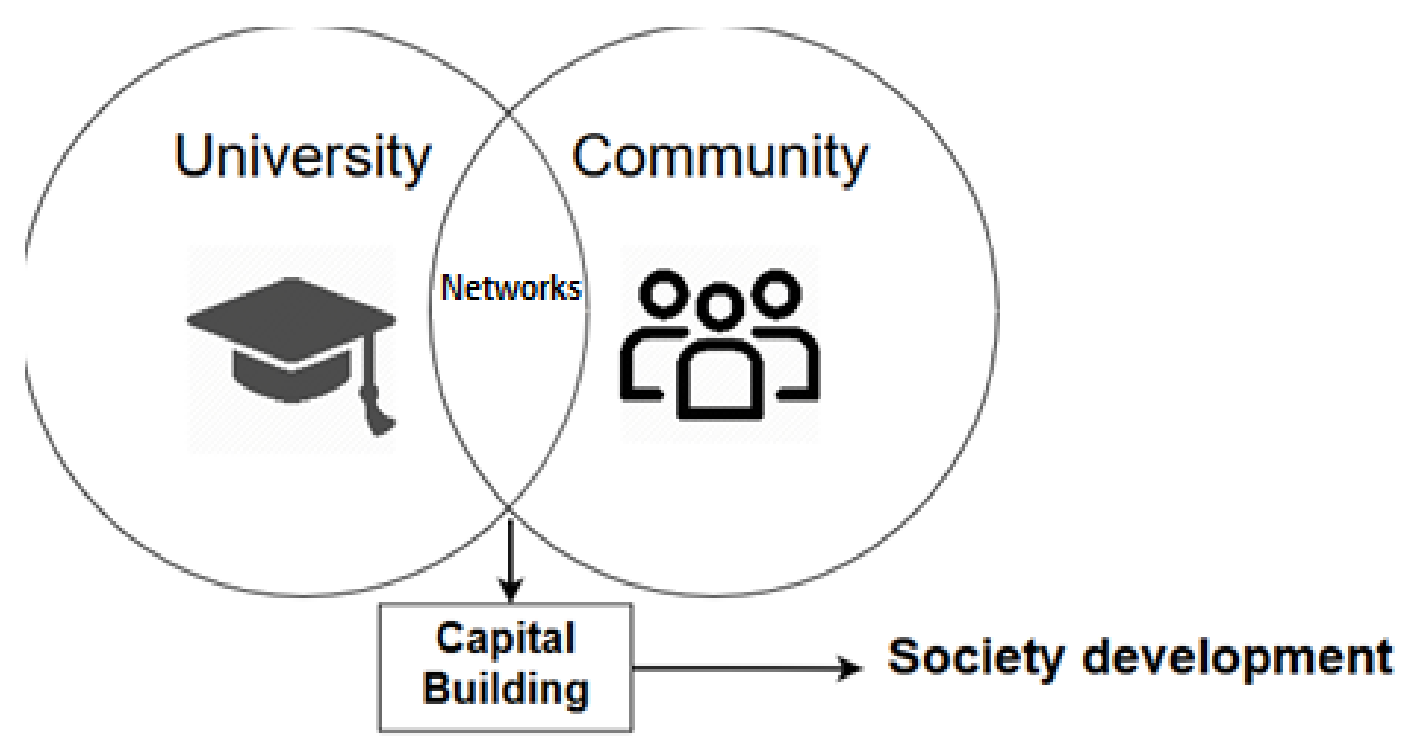

Figure 1. Networks and capital building

Source: Author's figure.

Since social capital resides within networks of people (OECD, 2007), maintaining these networks is vital for society development as the World Bank (2002) asserts,

[...] the norms, values, attitudes, and ethics that tertiary institutions impart to students are the foundation of the social capital necessary for constructing healthy civil societies and cohesive cultures.

In meeting socio-economic challenges, universities employ several strategies, including mobilising resources from firms, donors, governments, individuals and creating income-generating activities (IGAs) to sustain certain activities (Cloete et al., 2011). Universities can use the expertise of faculty and students from different disciplines to foster interaction with communities; and opening up of own facilities for communities to use (Preece, 2017). Universities create networks that allow communities to access resources and knowledge that would otherwise not have been accessible to local communities (Ström, 2011; 


\section{Macrothink}

Bloom, Canning, \& Chan, 2006; Brennan et al., 2004). Specifically in Africa, the World Bank (2002) further advocates for universities in today's knowledge-driven economies to use their positions to 'access existing stores of global knowledge and adapt it to local use' (p. 23). Universities in Africa can be a gateway to the World for rural communities who often have lower levels of education and have little links to formal economic channels outside the villages (Bloom et al., 2006). This linking function can create social capital for communities (please see Figure 1). However, universities operate within broad institutional and political contexts that may enable or hinder a society development agenda in the different forms of engagement. These contexts are concisely summarised in the following section.

\section{University-Community Engagement Contexts}

Any considerations of the university's role in Africa's society development may need to take into account the contexts in which universities operate. Different forces both within and outside the university, may hinder or enable the university's capacity to engage communities. Universities operate within national and international frameworks, in which socio-economic and political demands have a bearing on how they can fulfil the potential of community engagement (Kruss et al., 2012). National educational frameworks determine what is taught and how the teaching process takes place. At the same time, governments policies and regulations affect how individual university staff, departments, and faculties work with external partners such as communities. These laws and regulations can affect reward systems for the engaging staff, determine what is necessary, and decide the university's budget allocation. Among other things, the context (laws and regulations, availability of resources including funds, information dissemination and norms and values universities have to adhere to) can determine the extent to which university-community engagement is practised. Communities have their ways of working, which do not always fit in the universities' formal structures. The organisation of the community, the cultural beliefs, norms and values, may enable or hinder an engagement. Equally, the community operates differently with cultural values, local leadership and traditions determining what is of importance. 


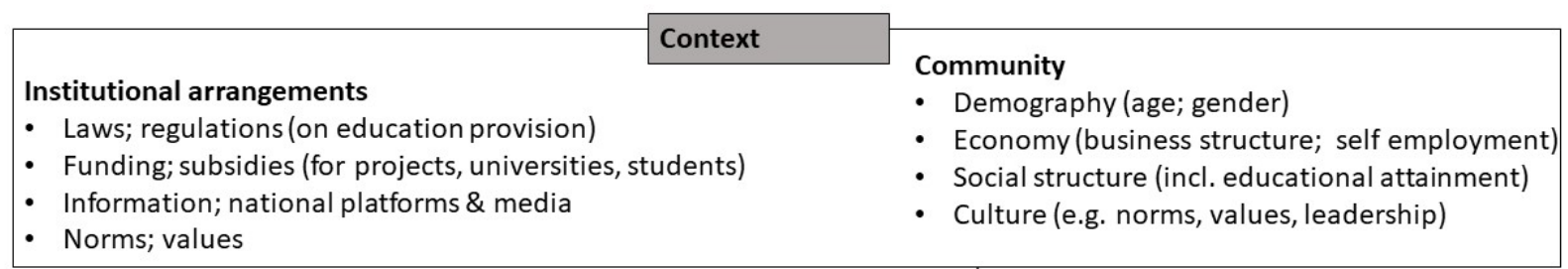

\begin{tabular}{|c|c|c|}
\hline & & Networks \\
\hline $\begin{array}{l}\text { Motivations } \\
\text { - Extrinsic } \\
\text { - Revenues (gov't + donor funds) } \\
\text { - Reputation/status/prestige } \\
\text { - Community/business needs }\end{array}$ & $\begin{array}{l}\text { University } \\
\text { Drivers (enablers/barriers) } \\
\text { - University leadership }\end{array}$ & $\begin{array}{l}\text { - } \quad \text { Number of participants } \\
\text { interaction } \\
\text { - Salience (power) of network } \\
\text { partners } \\
\text { - Scope \& nature of interaction }\end{array}$ \\
\hline $\begin{array}{l}\text { - Student demands } \\
\text { (e.g., career prospects) } \\
\text { - Intrinsic } \\
\text { - Mission (legitimacy) }\end{array}$ & $\begin{array}{l}\text { - } \quad \text { HR (staff rewards \& appraisal) } \\
\text { Internal resources (e.g. financial \& } \\
\text { infrastructural; ICT support) } \\
\text { - Organizational capacity \& }\end{array}$ & $\stackrel{\downarrow}{\text { Impact }}$ \\
\hline $\begin{array}{l}\text { - Learning/knowledge building } \\
\text { - Academic research \& its application } \\
\text { - Curriculum improvement }\end{array}$ & $\begin{array}{l}\text { - Ways of working \& internal } \\
\text { communication }\end{array}$ & $\begin{array}{l}\text { - Social capital } \\
\text { - Human capital } \\
\text { - Community development }\end{array}$ \\
\hline
\end{tabular}

Figure 2. UCE contexts

Source: Author's figure.

At the centre of this model is the university engaging the community. In this paper, the engagement activities take place with networks of people and organisations. These networks have several characteristics, such as the participants, frequency of interactions, the salience of the interacting partners and the scope and nature of these interactions. Critical areas of the model are explained here below.

The environment in which both the university and the community operate. These environments are essential in determining which action an organisation or community takes (OECD, 2007). These arrangements can include governing laws and regulations, availability of resources, social organisation, and norms and values. The university environment-its governing structures, motivations for (not) engaging communities, the university's resources, and its organisational capacity to respond to community needs-can enable or hinder an engagement. The community environment includes the demography, the social structure and economic activities. Also, culture is an essential aspect of understanding university-community engagement. The last area is the impact of such engagement for the stakeholders involved. At this final step, the actual results of engagement can be seen. It is essential to consider the contexts in which engagement can occur to map stakeholders and their inputs, thereby contributing to the understanding of how the university, through community engagement, can help create capitals necessary for society development. 


\section{Research Methodology}

This paper uses a case study methodology to address the research question. The case is representative of how universities interact with communities in Ghana. The case study use observations, in-depth interviews and documents reviews to understand UCC contribution to society development.

This paper leans epistemologically on realism, with some critical realist elements being applied. As opposed to direct realism ('what you see is what you get'), critical realism assumes that humans experience sensations and images of the natural world; however, it acknowledges that these sensations and images do not portray the complete picture of the phenomenon under study. Critical realism appreciates that interrelationships among individuals, groups, and organisations influence the 'truth' obtained through any research approach. Through approaching data collection and analysis using a critical realist philosophy, one acknowledges that the multiple sensations and images form a fragmented reality, which can collectively help derive understandings of the individual case under study (Eisenhardt, 1989). Case studies are used when 'how' or 'why' questions are being asked (Yin, 2009) and are useful in studying contemporary phenomena within a real-life context (Bell, 2005). As Yin (2009) suggests, case studies are helpful 'when the investigator has little or no control over events'. In this paper, a case study choice attempts to 'identify the various interactive processes at work, to show how they affect the implementation of systems and influence the way an organisation functions' (Bell, 2005). Although case study outcomes are challenging to generalise, Yin (2009) suggests that the conclusions drawn from a single case study may be specific to that case. The goal is not to generalise over a large population.

This single in-depth case study explores how the University of Cape Coast (UCC) contributes to creating social capital necessary for the Yamoransa community in the Central region of Ghana to meet development challenges. The case drew data from three sources: direct observations of the activities between UCC and the Yamoransa village, community engagement documents review at UCC and in-depth interviews with UCC representatives and beneficiaries of the engagement. In total, the engagement project was visited three times in four years, with data validation conducted through presentations, additional interviews and observations. A total of 11 community members representing community projects (please see Table 1) were interviewed. Data analysis uses UCE contexts to understand the contribution UCC makes to Yamoransa society development.

\section{The Case Study}

This community engagement case study is conducted at the University of Cape Coast (UCC) in Ghana's Central Region. The comprehensive university was established in 1962 as a Teacher's College and attained full university status in 1971. UCC's mission is to 'be a university of choice' with a vision of a 'University strongly positioned, with worldwide acclaim'. It has a student population of 19,965 (UCC Annual Report, 2017). The university embodied Kwame Nkrumah's (Note 1) vision of having a university that teaches African things, including local development initiatives, culture and traditions (Dwarko \& Kwarteng, 2003). Hence, the university's focus is on rural development. All undergraduate programmes 
demand that students spend time (ranging from two weeks to half a year) doing community work in the community; there are scholarships for bright students from low-income families and the university staff's involvement in local councils. The area around Cape Coast town experiences many children living on the street. Studies show that some causes for children to resort to the streets are rampant poverty, the HIV/AIDS pandemic and harmful traditional practices such as early marriages and female genital mutilation/cutting (Sackey \& Johannesen, 2015). Also, because children join in economic activities such as kenkey selling and petty trading very early, schools in the region have high drop-out rates (Frimpong-Manso, 2014). The university has responded to these challenges by introducing extension services, health screening services such as the one in Yamoransa, adult education at village centres and entrepreneurship centres linking villagers to the formal economy such as banking systems, and facilitating in trade unions' formation.

Yamoransa lies $12 \mathrm{~km}$ from UCC in the Mfantseman Municipality. It has 6000 people, with $40 \%$ of residents under 15 years (UCC Annual Report, 2017). The community has a low formal employment rate at $4.4 \%$, while informal employment takes up $40 \%$, with kenkey making and selling forming the bulk of the trade. Main economic activities are subsistence farming, small businesses, quarrying and fishing. Education attainment has a significant gender imbalance, with primary education being attended more by women (females $54.9 \%$ to males $45.1 \%$ ), while higher education has more males than women (males $75.2 \%$; females $24.8 \%$ ). The difference can be explained by the type of economic activities in the community where handmade crafts, foodstuff (e.g., kenkey, bread) are mainly an occupation for women. One of the main challenges to social and economic development at Yamoransa was identified as the gender gap in economic and social participation and educational attainment. For example, women selling kenkey on the streets of Yamoransa sometimes lost the money to their husbands or male counterparts upon returning home (Frimpong-Manso, 2014). Also, the lack of diversification in economic and social activities is one of the reasons why economic prosperity is not spreading to the majority in Yamoransa.

In Ghana, decentralisation has meant that the village's development efforts are the lowest unit to the national level. The National Development Planning Commission Act (Act 479, 1994) and the National Development Planning (Systems) Act (Act 480, 1994) gave provisions on overseeing development efforts (Sackey \& Johannesen, 2015). Thus, central to Ghana's development planning vision is the involvement of local councils as decision making bodies. The Yamoransa community has a local council headed by the village chief and assisted by the council of wise men and women. The council's membership is by lineage (chiefs, wise men and women), election (elected officials) and the central government's regional and district administrators. The local council is the linking line between the residents and the government. In 2007, the Yamoransa Local Council created the Yamoransa Community Development Committee (YCDC) to coordinate development initiatives. The committee has 25 members from the local council, UCC, Faith-Based Organisations (FBOs), representatives of local organisations, businesses and unions. 


\subsection{UCC and the Yamoransa Community Engagement}

UCC chose the Yamoransa community for engagement in 2010, following the request of the then dean of the College of Social Sciences, who sits at the Yamoransa Local Council. UCC then created a Yamoransa Social Lab at the Department of Health and Population to coordinate university programmes within Yamoransa community. The Yamoransa Social Lab offers practical hands-on advice and training (teaching and research) to Yamoransa villagers. The lab serves as a programme for service learning for the Department of Health and Population students who spend six weeks of their bachelor (third year) education doing research and taking part in community work. The following table summarises the projects chosen by the YCDC to work together with UCC.

Table 1. Summary of Yamoransa Projects with UCC involvement. NOTE: the number of interviewees is in brackets

\begin{tabular}{|c|c|c|c|}
\hline Project name & Description & UCC involvement & Partners involved \\
\hline $\begin{array}{l}\text { The Akroabeto } \\
\text { Kenkey selling group } \\
\text { (4 members) }\end{array}$ & $\begin{array}{l}\text { Cooperative for making and selling } \\
\text { kenkey; } \\
\text { Enhances women rights in } \\
\text { ownership of production means; } \\
\text { Had } 30 \text { members in } 2016 \text {; } \\
\text { Women only. }\end{array}$ & $\begin{array}{l}\text { Business and management } \\
\text { education; } \\
\text { Connected the group with mills, } \\
\text { banks for loans and deposits. }\end{array}$ & $\begin{array}{l}\text { Mills in Sekondi-Takoradi; } \\
\text { Local banks; } \\
\text { UCC School of Business } \\
\text { and Management. }\end{array}$ \\
\hline $\begin{array}{l}\text { The Yamoransa } \\
\text { Borbor Mfantse Kusum } \\
\text { Agormba Cultural Group } \\
\text { (1 member) }\end{array}$ & $\begin{array}{l}\text { Imparting skills to (mostly) street } \\
\text { children; } \\
\text { Dance and acrobatics training; } \\
25 \text { members. }\end{array}$ & $\begin{array}{l}\text { The Department of Music offers } \\
\text { training; } \\
\text { The group performs at UCC } \\
\text { graduations (and earn an income); } \\
\text { Connects the group with possible } \\
\text { customers (religious and } \\
\text { government events, for example). }\end{array}$ & UCC Department of Music. \\
\hline $\begin{array}{l}\text { The ICT/Community } \\
\text { Centre ( } 6 \text { members) }\end{array}$ & $\begin{array}{l}\text { Opened in } 2016 \text {; } \\
\text { Offers computer training, literacy } \\
\text { and sports; } \\
\text { Offers health services, such as } \\
\text { screening. }\end{array}$ & $\begin{array}{l}\text { Linked the centre with the Yale } \\
\text { Alumni Services Corps (YASC); } \\
\text { Students offer computer training } \\
\text { and sports; } \\
\text { Health checks. }\end{array}$ & $\begin{array}{l}\text { Yale Alumni Services Corps } \\
\text { (YASC); } \\
\text { American Foundry Society } \\
\text { (AFS) Ghana; } \\
\text { Vodafone Ghana. }\end{array}$ \\
\hline
\end{tabular}

Initially, the lab researched the health and population of the Yamoransa community. The idea behind the study was to understand how to deal with health issues in the village and to enrich the teaching curriculum on health and population. As the then dean put it:

We learn from indigenous knowledge. That is why it is about engagement. Our students learn from them [community] as we learn from them [community]. If there is an intention connected to going there, it is to learn. Learn from one another. It is not a matter of superior knowledge and imposing it on someone.

Students were also involved in teaching at local primary schools and worked on community projects such as cleaning public places. UCC appointed two staff members attending YCDC 
meetings on Tuesdays to present proceedings from the projects and get input from the village representatives. The dean who attends the Local Council meetings informs the chief and his council on the development of the Yamoransa Social Lab.

As interest grew in the students' work, the Local Council, through its YCDC, requested UCC for more help. There was the belief that UCC had the resources to meet development challenges at Yamoransa; as one project staff puts it 'sometimes people believe we can bring in money, but we cannot'. However, the UCC Department of Health and Population did not have all the expertise and resources needed to teach entrepreneurship, cultural troupe, and install computers (please see Table 1 above). Other requests related to health screening, which the department did not have the knowledge and the equipment. The situation started to cause tensions between the department and the council. The dean sought to engage the university's different colleges in the Yamoransa Social Lab. Some schools and departments responded to this request. For example, UCC's Department of Music started to work with the Cultural Group offering expertise in different fields, repairing instruments and sponsoring needy children to join the group. The School of Business and Management started training on entrepreneurship and the formation of unions to enhance collective actions. Group leaders in the village were trained on managing projects and how to access financial products and services.

As more requests came in for assistance from the community, the Social Lab turned into a liaising office for the development of Yamoransa. A network was created with the Yale Alumni Services Corps (YASC), which visit Ghana once a year for volunteering services. They started to volunteer in the construction of the ICT centre, offering sports training and health screening. Mills in Sekondi-Takoradi were linked to kenkey sellers in Yamoransa, where sellers can now get kenkey ingredients on credit and delivered to the village. Local banks in Cape Coast offer credits to businesses in Yamoransa but also help the community open bank accounts as individuals or as a group with the UCC Department of Health and Population guarantee. Vodafone Ghana was also brought in to help connect computers on the internet and bring in furniture for the computer room. The dean outlined some of these networks' achievements as:

We link them to the flour mill. They no longer need to go to the flour mill, but it now sells in the village. Companies supply the flour. Payments go through the bank. So you point out some things, and things get better.

Moreover,

We help them build a library/ICT centre; they had conceived five or six years before we came. We helped them mobilise things, so it got realised. We had a group of alumni helping to build, advising on entrepreneurship, working with men and women in business etc.

Other results of the engagement are such as the local organisations where community members have come together to increase their voice on issues of concern. Apart from the three selected projects, other examples of the currently active groups resulting from UCC 


\section{Macrothink}

training are the Bread Makers Union, the Drivers' Union, Schools Union, ICT and Sports Union, and an informal traders' club.

There have also been issues of different work cultures. The university works with timetables and needs reports for assessment for students; the community walks at a different pace, and time is cyclic. Also, networks that help Yamoransa develop were created by UCC, the sustainability of such networks when the university leaves are not clear. There has been an attempt to make Yamoransa Local Council responsible for the maintenance of these networks. However, the UCC's attendance of the Local Council and the YCDC meetings is voluntary; this has caused tensions as to the university's intentions. However, for a resources-poor community, it has proven both a financial and organisational burden.

\section{Analysis}

This case study aimed to understand how universities contribute to creating social capital through networks for society development. The case study has presented the Yamoransa Social Lab and the specific contribution of UCC in creating networks that help stakeholders access resources for their development. The Social Lab was a good beginning in establishing local engagement with the Yamoransa community. The table below summarises the UCE variables and how these affect the engagement: 
Table 2. Description and impact of UCE variables

\begin{tabular}{|c|c|c|c|}
\hline Variable & Items & Description & Impact on engagement \\
\hline $\begin{array}{l}\text { University } \\
\text { environment }\end{array}$ & $\begin{array}{l}\text { Laws: regulations (on } \\
\text { education); } \\
\text { Funding: subsidies; } \\
\text { Information: national platforms } \\
\text { \& media; } \\
\text { Norms: values }\end{array}$ & $\begin{array}{l}\text { Students must spend time in a community } \\
\text { (two weeks); } \\
\text { No specific funds allocated for community } \\
\text { services; } \\
\text { Publications and information on community } \\
\text { work is internally published; } \\
\text { The university follows an academic culture } \\
\text { and formal education is more valued than } \\
\text { community work. }\end{array}$ & $\begin{array}{l}\text { UCC initiates engagement; } \\
\text { Resources for engagement are external; } \\
\text { Unclear ownership of the engagement } \\
\text { activities; } \\
\text { Individual academics initiate contacts } \\
\text { with the community; } \\
\text { Engagement is sporadic. }\end{array}$ \\
\hline $\begin{array}{l}\text { The } \\
\text { community }\end{array}$ & $\begin{array}{l}\text { Demography; } \\
\text { Economy (business structure; } \\
\text { self-employment); } \\
\text { Social structure (incl. } \\
\text { educational attainment); } \\
\text { Culture (e.g., norms, values, } \\
\text { leadership) }\end{array}$ & $\begin{array}{l}6000 \text { people; } \\
40 \% \text { under } 15 \text { years; } \\
\text { Subsistence farming; } \\
\text { Kenkey selling; } \\
\text { Low formal education attendance; high } \\
\text { drop-out for girls; } \\
\text { Low formal employment; } \\
\text { Leadership is through the chief; } \\
\text { The YCDC coordinates development } \\
\text { projects. }\end{array}$ & $\begin{array}{l}\text { Low access to formal economic } \\
\text { channels; } \\
\text { Networks of families; no formal } \\
\text { unions/cooperatives; } \\
\text { Cultural prescriptions: both social } \\
\text { organisation and the economy follow } \\
\text { cultural norms. }\end{array}$ \\
\hline \multirow[t]{2}{*}{$\begin{array}{l}\text { Resources } \\
\text { allocation }\end{array}$} & $\begin{array}{l}\text { UCC does not allocate } \\
\text { resources for engagement; } \\
\text { Staff and students as resources; } \\
\text { Top university governance not } \\
\text { involved in engagement, }\end{array}$ & $\begin{array}{l}\text { Engagement as students placement; } \\
\text { Staff involvement in local councils; } \\
\text { Resources are sometimes from personal } \\
\text { belongings (cars, houses, teaching } \\
\text { materials, etc.). }\end{array}$ & $\begin{array}{l}\text { Engagement is network-funded; } \\
\text { Students conduct some research and } \\
\text { teach at local schools; } \\
\text { Different UCC departments are } \\
\text { involved on a personal note. }\end{array}$ \\
\hline & $\begin{array}{l}\text { Yamoransa has the workforce } \\
\text { and spaces (schools, farms, } \\
\text { etc.) }\end{array}$ & $\begin{array}{l}\text { Personal belongings; } \\
\text { Petty trading. }\end{array}$ & $\begin{array}{l}\text { Disjointed activities; } \\
\text { The family is the economic unit; } \\
\text { Low involvement in collective actions. }\end{array}$ \\
\hline
\end{tabular}

The involvement of the university staff in making decisions at the Local Council helped UCC establish community needs. Although the original aims of the Social Lab were to conduct research and offer students placement places, the lab grew to encompass socio-economic issues such as how to create businesses. Since community development challenges cannot be solved only through education, the creation of networks by UCC became useful in producing actual results. The involvement of different stakeholders with different resources within these networks helped create the social capital necessary for Yamoransa development. As Chatterton and Goddard (2003), suggest, being a member of such a network can link one to capitals they previously could not access. As Table 2 above shows, UCC involvement did not only create human capital (equipping individuals and groups with skills) it has also helped create social cohesion by encouraging the participation of different stakeholders. UCC links the Yamoransa community to networks allowing the community to access resources for the development. This is particularly important in rural Ghana, where access to resources is difficult for people without an education or who are not involved in (inter)national businesses. As Lin (2001) suggests, when networks are small in volume and are not rich in expertise, the output of such a network is also weak. 
Creating the networks required the personal involvement of members of UCC. These academics members often have networks extended beyond their local communities. They have the power of negotiation with the government and other institutions. They also have links to and knowledge about financial institutions operations and could influence the Local Council's decision-making.

The contexts in which UCC operates also offers insights into the struggles of engaging local communities. The Yamoransa case study shows that the engagement was emergent and different projects arose due to needs from the community, directives from the Ministry of Education, and donor agenda. It can also be noted that the dean who spearheaded the efforts in Yamoransa did it first on a personal title. With the request for the UCC to join in the efforts in Yamoransa not honoured, individual contacts within and outside UCC made it possible that the community requests, though not all, were met.

This analysis can draw several lessons when applying for the University-Community Engagement contexts (as shown in Table 2). First, to create social capital through engagement, one needs connectivity and embedding activities and plans in networks. This can be a complex relationship when the roles of those involved in the networks are not always clear (Holland \& Ramaley, 2008). In Yamoransa, the networks' nodal point was the dean, which can be problematic for ownership and sustainability of activities. Also, the contexts in which every engagement partner operates needs careful consideration.

Second, the salience of network members must be used at all times. In Ghana, the chief has almost absolute powers over his/her subordinates. Though discussed and approved by YCDC, decisions on the projects can only be implemented with the chief's blessing. Sackey and Johannesen (2015) also found that rural Ghana is traditional, and missing how important and complex these traditions are may cause a failure in any development project. Thus, the Yamoransa Social Lab could only succeed by carefully following traditions, especially data collection, reporting, and inviting other stakeholders to the village.

Three, the willingness of the community to organise itself is crucial for an engagement to be implemented successfully. Moore (2014) suggests that community engagement needs coordinated efforts from those involved. Different training at Yamoransa created human capital. Individuals with knowledge helped organise Yamoransans into unions, thereby increasing the decision-making powers and collectively undertake actions on their well-being. Leadership was needed to make action plans and provided by the YCDC in collaboration with UCC, as Table 2 shows). Thus, leadership is essential to creating a vision and a path towards achieving this vision. Also, the leadership from the department was influential in introducing the networks where community members drew resources. Without solid leadership, Holland and Ramaley (2008) say that limited interventions and occasional programmes cannot attract community partnerships or influence larger systems on the scale necessary to create change in communities.

Lastly, the organisation and the execution of engagement need to be inclusive for success. In the Yamoransa case, equipping the community with various knowledge first helped the community own the development process. Also, the dean sitting at the Local Council 
meetings every Tuesday helped establish engagement in the council members' minds before the engagement started. Preece (2017) emphasised that a two-way collaborative process has to be in place for engagement to work. This was particularly important for the Yamoransa case, as the university would not have been able to go to Yamoransa and start activities without this involvement at the council first. As the definition adopted in this paper suggests: community engagement is a relationship, an approach and a collaborative process between a university and a community that systematically or situationally enhances learning experiences to improve lives-Yamoransa project aimed at improving the community's lives by contributing to socio-economic activities. Although there is no comprehensive research done to map all the achievements, it is visible that some goals of this engagement have been successfully implemented. For example, kenkey sellers can now access financial services and have formed a union to foster their interests. Also, a group of women have formed a community at the community centre where they follow training on various social issues.

\section{Community Voices}

A total of 11 community members representing the three Yamoransa community projects were interviewed (Table 1). The representation is as follows: the Akroabeto Kenkey selling group (4), the Yamoransa Borbor Mfantse Kusum Agormba Cultural Group (1), and The ICT/Community Centre (6). The community members' views on the engagement were mainly positive. Representatives from the kenkey selling group had the following to say;

The committee has really done well with the UCC to organise this project. It has helped bring all the kenkey sellers together and also promote the work of kenkey making.

It's has improved my business and also made me know how to make good kenkey.

They have really done well and also helped the women in the community in the kenkey business. Not that alone we also bring in some regencies to talk to us in our meetings.

The council has done well, because of the group I have also trained my daughter how to make good kenkey, and she is now in Kumasi selling.

Although these experiences were positive, the process of change was not explained well. The kenkey sellers feel that the engagement has brought them together, helping them better understand skills and business competition concepts while offering them access to previously unavailable financial services. The main challenges as to the sustainability of this engagement were mentioned as poor contact with the YCDC and the meagre loans they get from banks. Members suggested the university could be a guarantor for the loans, something that is not happening now. Issues of the organisation for the community members were also identified as a challenge. For example, a member commented: The group is not meeting regularly' citing lack of commitment and the nature of kenkey selling which involves spending hours at the roadside.

Representatives from the ICT/Community Centre expressed what they felt the centre had helped them. Many comments aimed explicitly at the acquired knowledge of computer use and how the centre has acted as a place for people to come together to learn a skill and speak 
about community problems. Some of the comments are;

I thank God and the council a lot. This group has really transformed my life and also helped bring all the women together and do in-service training for ourselves.

ICT has helped us a lot. I now know how to use a computer. And all community is benefiting.

I thank the council for putting such a computer lab for us. It's has help the community of Yamoransa.

It has also improved my computer skills.

The community of Yamoransa is now proud of the ICT centre. Which has really helped me and my children in basic computer skills. Two of my children have benefited from it.

I was among the first to use the computer. It has really helped me and my classmates who were serious. I am very happy to use the computer on my own. Thanks all to the help of Yale University and the council.

It was striking to see that the university itself, which liaised with the Yale Alumni Service Corps and YCDC to build such a centre, was not mentioned in the responses. However, the first computer literacy instructors after the YASC established the centre came from UCC. The instructors were not directly involved with the development activities being coordinated by the YCDC. The members also commented on the challenges facing the centre. They cited poor computer maintenance and the lack of involvement by the Yamoransa council as the main issues facing the centre's sustainability. They suggested UCC help out increase the number of teaching staff and help diversify activities such as setting businesses using learnt computer and communication skills. Funding was also a challenge as YASC and Vodafone Ghana initially funded the centre; however, continued support is often uncertain.

The Cultural representative, who is also the instructor, was grateful for the engagement's opportunities. The cultural group has established several contacts where they get invited to perform at a fee. They also followed a training offered by UCC on public communication, choreography and playing different musical instruments. The representative says;

The training for the cultural group has really helped my sister and me a lot; it has helped us know how to communicate in public and also know how to drum and dance.

He, however, would like the YCDC to get more involved, especially after the children in the cultural group complete their training there. His suggestion is to have more funding to invest in self-employment skills in the performing art sector. He says the YCDC depends on donor help, which makes it difficult for the YCDC to make an actual plan to develop the cultural group. He says:

The council depends on the money from donors, so they do not have money themselves.

Although the engagement was mentioned as a fruitful endeavour, the cultural group believes that without finding their sources of funds, the YCDC cannot firmly push for the 
development agenda at Yamoransa.

\section{Discussion and Conclusion}

This paper sought to understand the university's contributions to society development by creating networks that increase social capital. The case study took place in the community's environment, which may lower the participation threshold for stakeholders. Increasing capital in Yamoransa meant that community members could take control of their destinies. This fits Preece's (2017) idea that community engagement is an essential medium through which knowledge can be co-created and applied. UCC involvement was mainly liaising partners to contribute to different development efforts in Yamoransa.

The analysis of the case study increases the understanding of the mechanisms behind community engagement, which may help map out actions that are crucial for an engagement to succeed. Cloete et al. (2011) presented the university's role in the development of Africa by encouraging innovation and acting as incubators for knowledge creation. As the TFHE (2000) shows, the university can act as a catalyst for society development. The Yamoransa case has shown that using its networks and available resources (students and own contributions) may be vital in encouraging rural community engagement. The university's role of liaising with social partners is thus essential as universities have networks that rural communities cannot access. As the voices of the community representatives also show, there is more to a university-community engagement than the initial setting of the engagement. Although the arrangement at Yamoransa is that the UCC works with the council and that the YCDC implements development programmes, there are still missing links between UCC and the community itself. Issues of organisation within community groups are seen as essential obstacles for the development of the Yamoransans, while these do not feature with equal measure at UCC. The main issue with this is that the community does not always know who is responsible for what. For example, the ICT/Community centre representatives mentioned UCC, YASC and YCDC interchangeably as being responsible for more computers, repair and binging in staff. UCC acted by creating the environment for engagement. Holland and Ramaley (2008) and Bloom et al. (2006) suggest that universities can create conditions where communities feel part of the action rather than being drawn to the action.

Although, as Chatterton and Goddard (2003), put it, the university plays an essential link to regional development, UCC's resources endowment meant that the university network, which is far-reaching than that of the local community, played a significant role in bringing in needed development resources. Yamoransa case shows that investing in skills and competencies for the community member can help human development by creating social capital. However, further investment in the actual application of these skills is even more needed. The sustainability of such an engagement was mentioned several times as being a challenge.

This paper has shown that university contributions to society development are non-linear and occur in the broader context of socio-economic and political constraints. Economic viability, which was Yamoransa's aim, was not fulfilled by the university, but by the university's intervention in bringing in specific stakeholders. 


\section{References}

Bell, J. (2005). Doing your Research Project: A guide for first-time researchers in education and social science (4th ed.). Buckingham: OUP.

Bloom, D., Canning, D., \& Chan, K. (2006). Higher Education and Economic Development in Africa. Washington DC: World Bank.

Brennan, J., King, R., \& Lebeau, Y. (2004). The Role of Universities in the Transformation of Societies. An International Research Report. London, UK: Association for Commonwealth Universities.

Burt, R. (2000). The Network Structure of Social Capital. Research in Organizational Behaviour, 22, 345-423. https://doi.org/10.1016/S0191-3085(00)22009-1

Chatterton, P., \& Goddard, J. (2003). The response of HEIs to regional needs. In F. Boekema, R. Rutten, \& E. Kuijpers (Eds.), Economic Geography of Higher Education: Knowledge, Infrastructure and Learning Regions (pp. 19-42). London, UK: Routledge.

Cloete, N., Bailey, T., \& Pillay, P. (2011). Universities and economic development in Africa. Cape Town: CHET African Minds. https://doi.org/10.47622/9781920355807

Coleman, J. S. (1988). Social Capital in the Creation of Human Capital. The American Journal of Sociology, 94, S95-S120. https://doi.org/10.1086/228943

Coleman, J. S. (1994). Social capital, human capital, and investment in youth. In A. C. Petersen \& J. T. Mortimer (Eds.), Youth unemployment and society (pp. 34-50). Cambridge University Press. https://doi.org/10.1017/CBO9780511664021.004

Dwarko, D. A., \& Kwarteng, K. O. (2003). A history of the University of Cape Coast: Forty years of resilience (1962-2002). Accra, Ghana: Woeli Publishing Services.

Eisenhardt, K. (1989). Building Theories from Case Study Research. Academy of Management Review, 14(4), 532-550. https://doi.org/10.5465/amr.1989.4308385

Field, J. (2003). Social capital. London, UK: Routledge. https://doi.org/10.4324/97802036 34080

Frimpong-Manso, K. (2014). Child Welfare in Ghana: The Past, Present and Future. Journal of Educational and Social Research, 4(6), 411. https://doi.org/10.5901/jesr.2014.v4n6p411

Grootaert, C., \& Van Bastelaer, T. (2001). Understanding and measuring social capital: A synthesis of findings and recommendations from the social capital initiative. Washington, DC: The World Bank.

Holland, B., \& Ramaley, J. (2008). Creating a supportive environment for community-university engagement: conceptual frameworks (pp. 33-47). Paper presented to HERDSA Annual Conference on Engaging Communities. Rotorua, New Zealand. 
Kruss, G., Visser, M., Aphane, M., \& Haupt, G. (2012). Academic interaction with social partners: Investigating the contribution of universities to economic and social development. Cape Town, South Africa: HSRC Press.

Lin, N. (2001). Social capital. A theory of social structure and action. Cambridge: Cambridge University Press. https://doi.org/10.1017/CBO9780511815447

Lockwood, A. (1996). Community collaboration and social capital: an interview with Gary G. Wehlage. Leaders for Tomorrow's Schools, 2(1), 19-25.

Misztal, B. A. (1996). Trust in Modern Societies: The Search for the Bases of Social Order. Cambridge, UK: Polity.

Moore, T. (2014). Community-University Engagement: A Process for Building Democratic Communities. ASHE Higher Education Report, 40(2), 1-129. https://doi.org/10.1002/ aehe. 20014

OECD (Organisation of Economic Co-operation and Development). (2007). Human Capital. How what you know shapes your life. Paris, France: OECD.

Preece, J. (2017). University Community Engagement and Lifelong Learning: The Porous University. London, UK: Palgrave Macmillan. https://doi.org/10.1007/978-3-319-56163-9

Preece, J., Ntseane, P., Modise, M., \& Osborne, M. (2012). Community Engagement in African Universities: Perspectives, Prospects and Challenges. Leicester, UK: NIACE.

Putnam, R. D. (2000). Bowling Alone: The collapse and revival of American community. New York: Simon and Schuster.

Rudd, T. (2003). ICT and the reproduction of inequalities: A Bourdieuian perspective (PhD thesis, University of Bristol, Bristol, UK).

Sackey, E., \& Johannesen, B. (2015). Earning identity and respect through work: A study of children involved in fishing and farming practices in Cape Coast, Ghana. Childhood, 22(4), 447-459. https://doi.org/10.1177/0907568214566079

Sawyerr, A. (2004). The Public Good, in African Higher Education: Select issues for policy. Newsletter of the Social Science, 5(1), 25-30.

Ström, J. (2011). Enabling engagement: A study of university-community engagement at a non-metropolitan Australian university ( $\mathrm{PhD}$ thesis, South Cross University, Lismore, Australia). Retrieved from https://researchportal.scu.edu.au/discovery/fulldisplay/alma991012 821331102368/61SCU_INST:ResearchRepository

The Taskforce on Higher Education and Society. (2000). Higher Education in Developing Countries. Peril and Promise. Washington D.C.: The International Bank for Reconstruction and Development/The World Bank. https://doi.org/10.1596/0-8213-4630-X

Thompson, N. M., \& Casely-Hayford, L. (2008). The Financing and Outcomes of Education in Ghana. Research Consortium on Educational Outcomes and Poverty RECOUP (Working Paper 


\section{Macrothink}

No. 16). Cambridge, UK: University of Cambridge. Retrieved from https://nbn-resolving.org/ urn:nbn:de:0168-ssoar-68683

UCC (University of Cape Coast). (2020). Annual Reports 2017-2020. Cape Coast, Ghana: UCC Press.

UNDP (United Nations Development Programme). (2019). Human Development Index (HDI). Retrieved from http://hdr.undp.org/en/content/human-development-index-hdi

Woolcock, M., \& Narayan, D. (2000). Social Capital: Implications for Development Theory, Research, and Policy. World Bank Research Observer, 15(2), 225-250. https://doi.org/ $10.1093 / \mathrm{wbro} / 15.2 .225$

World Bank. (2002). Constructing knowledge societies: New challenges for tertiary education. Washington, D.C: World Bank.

Yin, R. (2009). Case Study Research: Design and Methods. London, UK: Sage.

\section{Notes}

Note 1. The first president of the Republic of Ghana.

\section{Copyright Disclaimer}

Copyright for this article is retained by the author(s), with first publication rights granted to the journal.

This is an open-access article distributed under the terms and conditions of the Creative Commons Attribution license (http://creativecommons.org/licenses/by/3.0/). 